\title{
Effects of Prenatal Tobacco Exposure on Gene Expression Profiling in Umbilical Cord Tissue
}

\author{
NAVEED HUSSAIN, WINFRIED KRUEGER, JONATHAN COVAULT, STEPHEN WALSH, HENRY R. KRANZLER, \\ AND CHERYL ONCKEN
}

\author{
Departments of Pediatrics [N.H.]; Genetics and Developmental Biology [W.K.]; Psychiatry [J.C., H.R.K.]; Community Medicine [S.W.]; \\ Medicine and Obstetrics and Gynecology [C.O.], University of Connecticut School of Medicine, Farmington, Connecticut 06030
}

\begin{abstract}
Maternal smoking doubles the risk of delivering a low birth weight infant. The purpose of this study was to analyze differential gene expression in umbilical cord tissue as a function of maternal smoking, with an emphasis on growth-related genes. We recruited 15 pregnant smokers and 15 women who never smoked during pregnancy to participate. RNA was isolated from umbilical cord tissue collected and snap frozen at the time of delivery. Microarray analysis was performed using the Affymetrix GeneChip Scanner 3000. Six hundred seventy-eight probes corresponding to 545 genes were differentially expressed (i.e. had an intensity ratio $>$ \pm 1.3 and a corrected significance value $p<0.005)$ in tissue obtained from smokers versus nonsmokers. Genes important for fetal growth, angiogenesis, or development of connective tissue matrix were upregulated among smokers. The most highly upregulated gene was CSH1, a somatomammotropin gene. Two other somatomammotropin genes ( $\mathrm{CSH} 2$ and $\mathrm{CSH}-\mathrm{Ll}$ ) were also upregulated. The most highly downregulated gene was $A P O B E C 3 A$; other downregulated genes included those that may be important in immune and barrier protection. Validation of the three somatomammotropin genes showed a high correlation between $\mathrm{qPCR}$ and microarray expression. We conclude that maternal smoking may be associated with altered gene expression in the offspring. (Pediatr Res 64: 147-153, 2008)
\end{abstract}

A lthough a number of adverse perinatal, neonatal, and childhood health outcomes have been attributed to prenatal tobacco smoke exposure, the most consistent and measurable association is between prenatal tobacco exposure and low birth weight (1). Since low birth weight infants have an exponential increase in mortality rate compared with infants of normal birth weight (2), the public health significance of smoking during pregnancy is substantial. Moreover, low birth weight increases the risk for cardiovascular disease, metabolic syndrome, and type 2 diabetes among adults (3). The exact relationship between low birth weight and the onset of disease in adulthood is unknown. However, there has been growing evidence that environmental factors that cause fetal growth restriction may cause "fetal reprogramming," and increase the risk of disease in adulthood (3).

Received November 7, 2007; accepted March 8, 2008.

Correspondence: Cheryl Oncken, M.D., Department of Medicine, University of Connecticut School of Medicine, 263 Farmington Avenue, Farmington, CT 06030-3940; e-mail: oncken@nso2.uchc.edu

Supported by the State of Connecticut Department of Public Health Tobacco Research Funds, The Patrick and Catherine Weldon Donaghue Medical Research Foundation, and NIH grants RR06192 (University of Connecticut General Clinical Research Center), AA13736, and DA15167.

Supplementary material available online at www.pedresearch.com.
The aim of the present study was to examine the effects of prenatal tobacco exposure on mRNA expression in umbilical cord (UC) tissue. Tobacco smoke contains more than 4000 chemicals, including carcinogens and mutagens, which either alone or in combination may influence gene expression (4). Since the UC is exclusively fetal tissue, it may facilitate an examination of the effects of prenatal tobacco exposure on the fetal vascular system (5). Based on the magnitude of upregulation or downregulation of mRNA expression, we sought to identify the most differentially regulated genes in fetal tissue in relation to maternal smoking. This information may help to understand how smoking causes poor infant outcomes (including low birth weight) and increases the risk of childhood and adult diseases.

\section{MATERIALS AND METHODS}

The institutional review board at the University of Connecticut Health Center approved the study. Participants provided written consent before study procedures. Subjects were recruited from the labor and delivery unit at University of Connecticut Health Center. Inclusion criteria included gestational age $\geq 32$ wk and no active maternal infection. We administered a medical history (which elicited information on smoking, other drug use and medication use) before delivery. UC tissue was collected shortly after delivery. Infant outcomes were obtained from chart review.

Tissue collection and RNA isolation. UC tissue midway between infant and placenta was collected within $10 \mathrm{~min}$ postpartum, cut into $1.5 \mathrm{~cm}$ lengths, flash frozen by immersion in liquid nitrogen and stored at $-80^{\circ} \mathrm{C}$. A random sample of UC tissue was selected and RNA was isolated using a modified guanidinium isothiocyanate/ $\mathrm{CsCl}$ procedure (6). The frozen tissue was ground to a fine powder using a mortar and pestle cooled with liquid nitrogen, and ( $\sim 300 \mathrm{mg}$ ) transferred into a tube containing $1 \mathrm{~mL}$ of GTC lysis buffer ( $4 \mathrm{M}$ guanidinium isothiocyanate in $50 \mathrm{mM}$ sodium citrate, TrisHCl or HEPES, $0.1 \%$ sodium sarcosyl). Samples were then sheared using a polytron tissue disrupter to reduce the molecular weights of extracellular matrix material and genomic DNA.

For estimation of blood contamination, an aliquot was analyzed spectrophotometrically at a wavelength of $418 \mathrm{~nm}$. The homogenate was then layered on top of a $1.5 \mathrm{~mL}$ cushion of $\mathrm{CsCl}$ buffer $(5.7 \mathrm{M} \mathrm{CsCl} / 10 \mathrm{mM}$ sodium citrate $\mathrm{pH} 7.0$ and $1 \mathrm{mM}$ ethylene diamine tetraacetic acid), and centrifuged at $45,000 \mathrm{rpm}$, at $22^{\circ} \mathrm{C}$, in a SW50 rotor for $23 \mathrm{~h}$. RNA sediment was dissolved in $100 \mu \mathrm{L} \mathrm{H}_{2} \mathrm{O}$ (RNAsefree), concentrated by overnight precipitation at $-20^{\circ} \mathrm{C}$ in the presence of $0.3 \mathrm{M} \mathrm{NaOAc}$ and $75 \%$ ethanol (final concentration) and sedimented for $10 \mathrm{~min}$ at $15,000 \mathrm{rpm}$, at $4^{\circ} \mathrm{C}$, with the air dried pellets dissolved at a concentration of $\sim 1$ $\mathrm{mg} / \mathrm{mL}$. RNA was quantified by spectrophotometry at $260 \mathrm{~nm}$, and purity examined by $260 / 280$ ratio. RNA quality was further examined by electrophoresis on a $1.1 \%$ agarose/2.2M formaldehyde gel.

Microarray hybridization. For each sample, $1.5 \mu \mathrm{g}$ of RNA was converted into biotinylated cRNA and hybridized to arrays following protocols supplied by the array manufacturer (Affymetrix, Santa Clara, CA). The RNA was used for first and second strand cDNA synthesis and the double-stranded cDNA

Abbreviations: cRNA, copy ribonucleic acid; qPCR, quantitative polymerase chain reaction; $\mathbf{U C}$, umbilical cord 
was transcribed in the presence of biotinylated ribonucleotides to generate biotinylated cRNA, which was then purified by ion exchange column chromatography. The biotinylated cRNA was fragmented, and hybridized to human U133 Version 2.0 Plus GeneChips (Affymetrix, Santa Clara, CA) without technical replication. The chip includes 54,674 probes covering all currently identified transcripts (over 47,000 transcripts from $\sim 39,000$ genes). After $16 \mathrm{~h}$ of hybridization at $45^{\circ} \mathrm{C}$, the arrays were stained in an Affymetrix Fluidics Station using a two-stage signal amplification protocol based on detection of the biotinylated targets by streptavidin-phycoeritherin (SAPE) according to Affymetrix instructions. The signal was quantified by detection of bound phycoerythericin using an Affymetrix GeneChip Scanner 3000.

Quantitative polymerase chain reaction methodology. Total RNA (100 ng) was reverse transcribed using a commercial kit (High Capacity cDNA Archive, Applied Biosystems Inc. ABI, Foster City, CA) in parallel with calibrator total RNA from pooled human tissues (Universal Reference Total RNA PN636690, Clontech Laboratories, Mountain View, CA). Triplicate TaqMan real-time PCR reactions were prepared with cDNA from $2 \mathrm{ng}$ of RNA and amplified in 384-well plates using an ABI 7900HT Sequence Detection System. Average threshold cycle number $(\mathrm{Ct})$ for each sample was converted to the equivalent amount of the calibrator RNA by use of standard curves on each plate of cDNA prepared from pooled human tissue reference RNA. Relative amounts of target RNAs were normalized to the amount of two ubiquitously expressed genes encoding beta-2 microglobulin $(B 2 M)$, and glyceraldehyde phosphate dehydrogenase $(G A P D H)$. Premade and validated TaqMan quantitative polymerase chain reaction (qPCR) probe and primers for each target or reference gene were obtained from Applied Biosystems (Hs01862611_g1 chorionic somatomammotropin hormone 1 [placental lactogen, CSH1]; Hs00831897_s1 chorionic somatomammotropin hormone 2 [CSH2]; Hs00741469_g1 chorionic somatomammotropin hormone-like [CSHL1]; 4326319E-0411004 B2M; 4326317E-0411007 GAPDH). Controls in which the reverse transcriptase was omitted from the RT reaction produced no amplification during the $\mathrm{qPCR}$ TaqMan reaction.

Microarray analyses. Microarray analysis was conducted using the R/MAANOVA open source software (Version 1.4) as part of the Bioconductor and R language open source software library (Version 2.4.0) (7). Robust Multiarray Averaging (RMA) is an analysis option within the R/MAANOVA package and a commonly applied technique for normalization of Affymetrix arrays. Statistical analysis was performed on RMA-normalized data using R/MAANOVA (8) with a fixed effect permutation ANOVA model consisting of the independent variable, smoking status (smoker versus nonsmoker), and the covariables gender of the offspring, and $\mathrm{Hb}$ content of the UC lysates (which controlled the analysis for the degree of UC contamination by blood). Using the magnitude of absorption at $418 \mathrm{~nm}$ for each sample as an indicator of its $\mathrm{Hb}$ (and by extension $\mathrm{Hb}$ mRNA) content, we trichotomized the samples into those with low absorption $\left(\mathrm{OD}_{418}<1.5\right)$, intermediate absorption $\left(\mathrm{OD}_{418}\right.$ $<2.5)$, and high blood content $\left(\mathrm{OD}_{418} \geq 2.5\right)$.

To identify differentially regulated genes, we performed the F-tests F1, F2, $\mathrm{F} 3$, and Fs that are implemented in the R/MAANOVA software and assessed gene-centric (F1-test) and array centric (F3 test) variance through comparison of the respective lists of regulated genes with those provided by the F2 and Fs-tests, which interpolate between gene centric and array centric variance. R/MAANOVA uses the Benjamini Hochberg test to perform the false discovery rate, which was set to a $p$ value of $<0.005$, and pooled across all gene lists to create an inclusive master list. We selected the subset of highly significantly differentially regulated genes that demonstrated a change in their expression level of at least 1.3-fold.

The differentially regulated genes were organized into clusters using the hierarchical clustering module of D-Chip software (revised 2006) (7) by both genes and samples with the clustering parameter set to (a) Euclidian distance and (b) a $p$ value of 0.05 . Differentially expressed genes were annotated using all publicly available databases including the ENTREZ, gene ontology, and IHOP databases.

Analysis of clinical variables. Analyses were conducted using SPSS software, version 15 (SPSS, Inc., Chicago, Illinois) and StatXact, version 4 (Cytel Software Corp., Cambridge, Massachusetts). Summary statistics (means, standard deviations, and percentages) were calculated to describe the characteristics of subjects in the study samples. For continuous variables, mean values were compared using the two-sample t test. For categorical variables, distributions of frequencies between samples were compared using the $\chi^{2}$ test or the Fisher exact test.

Validation of microarray results using qPCR. For the $\mathrm{CSH} 1, \mathrm{CSH} 2$, and CSHL1 genes, relationships between gene expression values as measured by qPCR and by microarray analysis were evaluated with correlation coefficients and their corresponding $p$ values. In these analyses, gene expression values were normalized using expression levels of the $B 2 M$ gene. The Spearman rank correlation coefficient was applied to account for skewness. Microarray expression values of different probes related to the same gene were averaged (after logarithmic transformation) to determine a single expression value before calculating a correlation with the qPCR value for the same gene.

\section{RESULTS}

Demographics of the subject population are shown in Table 1. Smokers were younger and they delivered infants at an earlier gestational age and at a lower birth weight than nonsmokers. Smokers were also more likely to report other drug use during pregnancy. Additionally, the proportion of male offspring born to nonsmoking mothers was higher. Other characteristics were similar between groups.

Six hundred seventy-eight probes corresponding to 545 genes were differentially expressed (i.e. an intensity ratio that exceeded \pm 1.3 and a corrected significance value $p<0.005$ ) in tissue obtained from smokers versus nonsmokers. Of the 545 genes, 371 were upregulated and 174 were downregulated in smokers. Of the 545 differentially regulated genes, 458 genes are known. Only 87 probe identification numbers were not annotated as determined by the absence of a gene symbol.

The 25 genes with the largest increase or the largest decrease in mRNA abundance in the UC tissue of smokers compared with that of controls are shown in Tables 2 and 3. If more than one probe for the same gene was differentially expressed the mean value of the various probes is reported.

Hierarchical clustering based on similarity in gene expression using all differentially expressed genes $(>1.3$-fold increased or decreased RNA level) tied cases into two major groups (Fig. 1). One group consisted of nine nonsmokers and two

Table 1. Characteristics of the study population (count, mean \pm s.d., or percent, as indicated)

\begin{tabular}{|c|c|c|c|}
\hline & $\begin{array}{c}\text { Non-smoking } \\
\text { mothers }\end{array}$ & $\begin{array}{c}\text { Smoking } \\
\text { mothers }\end{array}$ & $p$ \\
\hline Number of subjects & 15 & 15 & \\
\hline Maternal age (y) & $29.8 \pm 5.5$ & $26.2 \pm 6.5$ & 0.12 \\
\hline Caucasian/white race & $46.7 \%$ & $60.0 \%$ & 0.62 \\
\hline Hispanic ethnicity & $26.7 \%$ & $20.0 \%$ & 0.68 \\
\hline Gravidity/total pregnancies & & & 0.26 \\
\hline 1 & $26.7 \%$ & $20.0 \%$ & \\
\hline 2 & 53.3 & 20.0 & \\
\hline 3 & 6.7 & 20.0 & \\
\hline$\geq 4$ & 13.3 & 33.3 & \\
\hline Unknown & 0.0 & 6.7 & \\
\hline Parity/prior births & & & 0.06 \\
\hline 0 & $33.3 \%$ & $40.0 \%$ & \\
\hline 1 & 60.0 & 20.0 & \\
\hline$\geq 2$ & 6.7 & 33.3 & \\
\hline Unknown & 0.0 & 6.7 & \\
\hline Maternal body mass index & $30.1 \pm 5.4$ & $32.4 \pm 6.8$ & 0.33 \\
\hline $\begin{array}{l}\text { Evidence of alcohol } \\
\text { or drugs at delivery }\end{array}$ & $0.0 \%$ & $33.3 \%$ & 0.04 \\
\hline Infant sex & & & 0.07 \\
\hline Male & $60.0 \%$ & $26.7 \%$ & \\
\hline Female & 40.0 & 73.3 & \\
\hline Gestational age (wk) & $38.9 \pm 1.5$ & $36.8 \pm 2.5$ & 0.01 \\
\hline Infant weight $(\mathrm{g})$ & $3319 \pm 425$ & $2610 \pm 911$ & 0.01 \\
\hline Infant length (in) & $19.9 \pm 1.2$ & $18.0 \pm 1.8$ & 0.004 \\
\hline \multicolumn{4}{|l|}{ Cigarettes/d } \\
\hline Before pregnancy & & $20.6 \pm 10.2$ & \\
\hline In week before study entry & & $6.9 \pm 8.7$ & \\
\hline During 1st trimester & & $14.5 \pm 8.6$ & \\
\hline During 3rd trimester & & $10.5 \pm 7.8$ & \\
\hline
\end{tabular}


Table 2. Up-regulated genes in smokers (limited to 25)

\begin{tabular}{|c|c|c|c|c|c|c|}
\hline Entrez ID & Symbol & Mean ratio & P_IDs & Gene name & Gene function & $\begin{array}{l}\text { Potential role } \\
\text { in development }\end{array}$ \\
\hline 1442 & CSHI & 2.48 & 211739_X_at & Chorionic somatomammotropin hormone 1 & Fetal growth & GS (15) \\
\hline 3050 & $H B Z$ & 2.26 & 206647_at & Hemoglobin, zeta /// hemoglobin, zeta & $\mathrm{O} 2$ binding & HY (40) \\
\hline 4629 & MYH11 & 2.23 & 1568760_at & Myosin, heavy polypeptide 11 , smooth muscle & Hematopoieses & $\mathrm{TM}(28)$ \\
\hline 58155 & РТВР2 & 2.17 & 1560271_at & Polypyrimidine tract binding protein 2 & Cell cycle & CG (41) \\
\hline 1443 & $\mathrm{CSH} 2$ & 2.16 & 203807_×_at & Chorionic somatomammotropin hormone 2 & Collagen synthesis & GS (15) \\
\hline 3371 & $T N C$ & 2.12 & 216005_at & Tenascin C (hexabrachion) & Tissue component & CG (24) \\
\hline 6453 & ITSN1 & 2.07 & 215791_at & Intersectin 1 (SH3 domain protein) & Endocytosis & GS (21) \\
\hline 2120 & ETV6 & 2.03 & 1561167_at & Ets variant gene 6 (TEL oncogene) & Fusion protein & AG (42) \\
\hline 4628 & МYH10 & 2.03 & 237491_at & Myosin, heavy polypeptide 10 , non-muscle & Cytokinesis & $\mathrm{TM}(27,43)$ \\
\hline 23240 & KIAA0922 & 2.03 & 239946_at & KIAA0922 & & \\
\hline 51379 & $C R L F 3$ & 2.01 & 235803_at & Cytokine receptor-like factor 3 & & \\
\hline 81 & ACTN4 & 2 & 241788_X_at & Actinin, alpha 4 & Cell motility & TM (26) \\
\hline 10658 & $C U G B P 1$ & 2 & 242440_at & CUG triplet repeat, RNA binding protein 1 & Translation p21 & $\mathrm{TM}$ \\
\hline 6310 & ATXN1 & 1.99 & 232744_×_at & Ataxin 1 & Trinucletide repeats & \\
\hline 653471 & LOC653471 & 1.98 & 217653_X_at & Ribosome biogenesis protein BMS1 homolog & & \\
\hline 643314 & KIAA0754 & 1.97 & 215268_at & Hypothetical LOC643314 & & \\
\hline 8847 & $D L E A H 2$ & 1.95 & 1556821 ×_at & Deleted in lymphocytic leukemia, 2 & & \\
\hline 1444 & CSHL1 & 1.94 & 205958 X_at & Chorionic somatomammotropin hormone-like 1 & Fetal growth & GS (15) \\
\hline 1523 & CUTL1 & 1.94 & 240798_at & Cut-like 1, CCAAT displacement protein & Gene expression & CG (44) \\
\hline 11030 & $R B P M S$ & 1.94 & 241897_at & RNA binding protein with multiple splicing & Cell growth & CG (45) \\
\hline 11039 & SMA4 & 1.94 & 215599_at & SMA4 /// similar to beta-glucuronidase precursor & & \\
\hline 8662 & EIF3S9 & 1.93 & 242550_at & Eukaryotic translation initiation factor 3 , sub 9 & & CG (46) \\
\hline 51232 & CRIM1 & 1.93 & 233073_at & Cysteine rich transmembrane BMP regulator 1 & Capillary formation & AG (22) \\
\hline 23433 & $R H O Q$ & 1.91 & 239258_at & Ras homolog gene family, member Q & Exocyst complex & CG (47) \\
\hline 4919 & ROR1 & 1.89 & 1559394_a_at & Receptor tyrosine kinase-like orphan receptor 1 & Neurite growth & TM \\
\hline
\end{tabular}

CG, cell and organ growth; AG, angiogenesis; TM, tissue and matrix remodeling; GS, growth-related signals; BI, barrier and immune function; HY, hypoxia related responses.

Table 3. Down-regulated genes in smokers (limited to 25)

\begin{tabular}{|c|c|c|c|c|c|c|}
\hline Entrez ID & Symbol & Mean ratio & P_IDs & Gene name & Gene function & $\begin{array}{l}\text { Potential role } \\
\text { in development }\end{array}$ \\
\hline 200315 & АРОВЕС $3 A$ & -2.78 & 210873_×_at & Apolipoprotein B mRNA editing enzyme & Cell regulation & BI (32) \\
\hline 4680 & CEACAM6 & -2.72 & 211657_at & Carcinoembryonic antigen-related CAM 6 & Tissue architecture & $\mathrm{CG}(48)$ \\
\hline 2568 & $G A B R P$ & -2.53 & 205044_at & $\gamma$-aminobutyric acid (GABA) A receptor, pi & & \\
\hline 25984 & KRT23 & -2.48 & 218963_s_at & Keratin 23 (histone deacetylase inducible) & Structural protein & BI (49) \\
\hline 114569 & MAL2 & -2.45 & 224650_at & Mal, T-cell differentiation protein 2 & Transcytosis & BI (34) \\
\hline 3854 & KRT6B & -2.39 & 213680_at & Keratin 6B & Structural protein & BI (49) \\
\hline 5275 & SERPINB13 & -2.34 & 211361_s_at & Serpin peptidase inhibitor, clade B (ovalbumin) & Inhibit proteinases & AG (23) \\
\hline 220 & $A L D H 1 A 3$ & -2.31 & 203180_at & Aldehyde dehydrogenase 1 family, member A3 & Detoxification & \\
\hline 144568 & $A 2 M L 1$ & -2.29 & 1564307_a_at & $\alpha$-2-macroglobulin-like 1 & Inhibit proteases & $\mathrm{BI}(35)$ \\
\hline 647456 & $C D 24$ & -2.29 & 208650_s_at & CD24 molecule & Cell receptor & \\
\hline 5918 & RARRES1 & -2.28 & 221872_at & Retinoic acid receptor responder 1 & Retinoic acid related & \\
\hline 8796 & SCEL & -2.28 & 232056_at & Sciellin & Cell differentiation & BI (30) \\
\hline 6947 & TCN1 & -2.27 & 205513_at & Transcobalamin I (vitamin B12 binding protein) & & \\
\hline 5055 & SERPINB2 & -2.25 & 204614_at & Serpin peptidase inhibitor, clade B (ovalbumin) & $\begin{array}{l}\text { PAI-2 (proteinase } \\
\text { inhibitor) }\end{array}$ & TM (25) \\
\hline 3934 & $L C N 2$ & -2.18 & 212531_at & Lipocalin 2 (oncogene 24p3) & $\begin{array}{l}\text { Granulocyte } \\
\text { maturation }\end{array}$ & BI (36) \\
\hline 4118 & $M A L$ & -2.17 & 204777_s_at & Mal, T-cell differentiation protein & T-cell differentiation & BI (33) \\
\hline 8710 & SERPINB7 & -2.16 & 206421_s_at & Serpin peptidase inhibitor, clade B megsin & Proteinase inhibitor & AG (38) \\
\hline 3713 & $I V L$ & -2.11 & 214599_at & Involucrin & $\begin{array}{l}\text { Epidermal } \\
\quad \text { differentiation }\end{array}$ & \\
\hline 26298 & $E H F$ & -2.11 & 225645_at & Ets homologous factor & $\begin{array}{l}\text { Transcriptional } \\
\text { repressor }\end{array}$ & BI (37) \\
\hline 9052 & GPRC5A & -2.1 & 203108_at & G protein-coupled receptor, family $\mathrm{C}$, group 5 & $\begin{array}{l}\text { Cell growth } \\
\text { promotion }\end{array}$ & \\
\hline 6698 & SPRR1A & -2.01 & 214549_×_at & Small proline-rich protein $1 \mathrm{~A}$ & & $\mathrm{CG}$ \\
\hline 3860 & KRT13 & -2 & 207935_s_at & Keratin 13 & Structural protein & BI (49) \\
\hline 6699 & SPRRIB & -2 & 205064_at & Small proline-rich protein 1B (cornifin) & Disrupts mitosis & CG \\
\hline 6707 & $S P R R 3$ & -2 & 232082_×_at & Small proline-rich protein 3 & Neoplastic marker & $\mathrm{BI}$ \\
\hline 1824 & $D S C 2$ & -1.97 & 204751_×_at & Desmocollin 2 & & \\
\hline
\end{tabular}


smokers and the other group consisted of six nonsmokers and 13 smokers. The largest cluster of transcripts (cluster 1) consisted of 431 probes that predominantly were upregulated in smokers compared with nonsmokers. The second largest cluster (cluster 4)

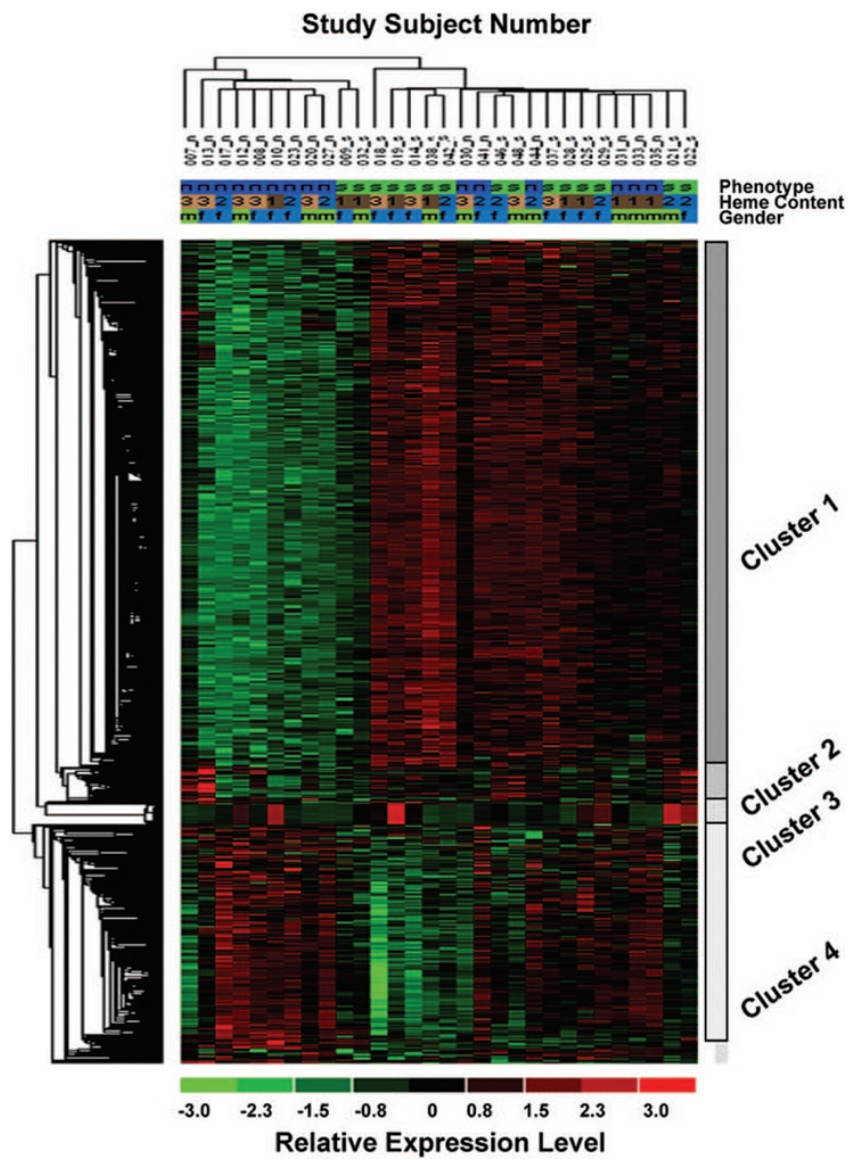

Figure 1. Hierarchical clustergram. Six hundred seventy-eight probes identified through ANOVA as being significantly regulated among the 30 subjects were clustered using the hierarchical clustering module in the D-Chip software using Euclidian distance and at a cluster significance value of 0.05 . Two major subgroups of subjects (Phenotype: $\mathrm{s}=$ smokers; $\mathrm{n}=$ nonsmokers) and four major clusters of probes can be identified (discussed in the text). Heme content $(1=$ low, $2=$ moderate, $3=$ high $)$ and sex of the baby $(\mathrm{m}=$ male, $\mathrm{f}=$ female) were used as covariates in ANOVA. The relative expression for each individual at a given probe is reflected by its color intensity (green $=$ downregulated, red $=$ upregulated). consisted of 197 probes that were primarily downregulated in smokers compared with nonsmokers. Further, small groups of genes (cluster 2 and 3 with 28 and 17 probes, respectively), did not show a consistent pattern of change as a function of smoking status. The genes in each cluster can be found in Supplementary Data Table 1 (available online at www.pedresearch.com). All genes that were examined in this microarray analysis can be found at GEO (http://www.ncbi.nlm.nih.gov/geo). Gene ontology analysis was performed with the DAVID ontology program V2.0 (9) using the lists of Affymetrix identification numbers for genes with either increased or decreased gene expression $(>1.3-$ fold) in UC tissue from smokers. The upregulated and downregulated set of genes were each classified into five biologic functional families as shown in Table 4.

The correlation coefficients between qPCR and microarray gene expression values for $C S H 1, C S H 2$, and $C S H L 1$ were +0.73 , +0.68 , and +0.69 , respectively $(p<0.0001)$ as shown in Table 5.

\section{DISCUSSION}

To our knowledge, this is the first study to examine the effects of prenatal tobacco exposure on gene expression in the UC of infants born to smokers. As expected, we found that cigarette smoking was associated with reduced birth weight $(1,10)$. Using microarray analysis of UC tissue, we identified 545 genes that were differentially expressed as a function of smoking status. Differentially expressed genes seem to cluster into a number of categories, including those involved in growth factor signaling or direct growth promotion, cellular growth, and differentiation, angiogenesis, extracellular matrix remodeling and connective tissue growth, and barrier and immune function. Correlation of the expression levels of three somatomammotropin genes with the qPCR results supported the validity of the microarray results.

Tobacco smoke is a complex mixture of toxicants, a number of which (e.g. carbon monoxide, hydrogen cyanide, nicotine, carcinogens) have been implicated in reducing fetal growth (4). Consistent with the theory that carcinogens may play a role in reduced birth weight, Wang et al. (11) found that pregnant smokers with the inducible CYP1Al genotype were more likely to deliver a low birth weight baby than smokers

Table 4. Gene ontology classification using DAVID to group genes of similar functional families

\begin{tabular}{|c|c|c|c|}
\hline Group & No of genes & Enrichment score & Type of gene \\
\hline \multicolumn{4}{|c|}{ Upregulated* } \\
\hline 1 & 71 & 6.37 & Transcription regulatory/nuclear \\
\hline 2 & 14 & 5.8 & RNA binding or RNA processing proteins \\
\hline 3 & 23 & 5.1 & Primary metabolism/protein metabolism \\
\hline 4 & 24 & 4.27 & Protein kinases \\
\hline 5 & 10 & 2.36 & Vesicle associated intracellular transport \\
\hline \multicolumn{4}{|c|}{ Downregulated $\dagger$} \\
\hline 1 & 18 & 5.62 & Transmembrane protein \\
\hline 2 & 19 & 4.47 & $\begin{array}{l}\text { Immunoglobulin domain containing } \\
\text { transmembrane protein }\end{array}$ \\
\hline 3 & 7 & 4.4 & Cytoskeleton/intermediate filament protein \\
\hline 4 & 4 & 3.16 & Membrane protein \\
\hline 5 & 6 & 3.01 & Epidermal morphogenesis \\
\hline
\end{tabular}

\footnotetext{
* There were 472 upregulated Affymetrix IDs with 384 matching DAVID dataset entries. Of these 142 were grouped.
}

$\dagger$ There were 201 downregulated Affymetrix IDs with 170 matching DAVID dataset entries. Of these 54 were grouped. 
Table 5. Spearman rank correlation coefficients between QPCR and microarray expression values for the same gene

\begin{tabular}{|c|c|c|c|c|c|}
\hline \multirow[b]{2}{*}{ QPCR gene } & \multirow[b]{2}{*}{ Microarray probe } & \multicolumn{2}{|c|}{$B 2 M$ normalization } & \multicolumn{2}{|c|}{ GAPDH normalization } \\
\hline & & Corr. & $p$ & Corr. & $p$ \\
\hline \multirow[t]{6}{*}{$\mathrm{CSH} 1$} & CSH1-202493_×_at & +0.77 & $<0.0001$ & +0.76 & $<0.0001$ \\
\hline & CSH1-206475_×_at & +0.63 & 0.0002 & +0.62 & 0.0002 \\
\hline & CSH1-208356_×_at & +0.72 & $<0.0001$ & +0.74 & $<0.0001$ \\
\hline & CSH1-208357_×_at & +0.74 & $<0.0001$ & +0.74 & $<0.0001$ \\
\hline & CSH1-211739_×_at & +0.69 & $<0.0001$ & +0.70 & $<0.0001$ \\
\hline & CSH1-208068_×_at & +0.63 & 0.0002 & +0.65 & 0.0001 \\
\hline \multirow[t]{5}{*}{$\mathrm{CSH} 2$} & CSH2-203807_×_at & +0.63 & 0.0002 & +0.65 & 0.0001 \\
\hline & CSH2-207770_×_at & +0.58 & 0.0008 & +0.56 & 0.001 \\
\hline & CSH2-207770_×_at1 & +0.59 & 0.0006 & +0.58 & 0.0007 \\
\hline & CSH2-208341_×_at & +0.72 & $<0.0001$ & +0.74 & $<0.0001$ \\
\hline & CSH2-208342_X_at & +0.75 & $<0.0001$ & +0.77 & $<0.0001$ \\
\hline \multirow[t]{5}{*}{ CSHL1 } & CSHL1-205958_×_at & +0.64 & 0.0001 & +0.64 & 0.0001 \\
\hline & CSHL1-207285_×_at & +0.63 & 0.0002 & +0.62 & 0.0002 \\
\hline & CSHL1-208293_×_at & +0.61 & 0.0003 & +0.63 & 0.0002 \\
\hline & CSHL1-208294_×_at & +0.67 & $<0.0001$ & +0.67 & $<0.0001$ \\
\hline & CSHL1-208295_×_at & +0.79 & $<0.0001$ & +0.78 & $<0.0001$ \\
\hline
\end{tabular}

with the wild type variant. Further, one recent study examining the effects of tobacco exposure on gene expression in placental tissue (a composite of maternal and fetal tissue) found that phase 1 drug metabolism genes (particularly CYP1A1) were upregulated in smokers (12). Our study differs from that study in that we examined the effect of tobacco exposure on UC tissue (which is exclusively fetal tissue). The results that we obtained may reflect effects of prenatal tobacco exposure on fetal vascular gene expression. The difference in results from these two studies of gene expression may be explained by the fact that different areas in the placenta have differing patterns of gene expression, whereas the UC is not typically involved in drug metabolism.

Although, the exact mechanisms are unknown (13), changes in the pattern of gene expression in the UC tissue of smokers can be understood in the context of fetal adaptation to a nutrient-poor, or growth-limiting, environment. For example, studies of the effects of fetal malnutrition and anemia suggest that with fetal adaptation there are increases in growth-related genes, especially those encoding growth hormone $(G H 1, G H 2)$ and chorionic somatomammotropin (CSH-1, CSH-2 and CSH-L genes) (14). These genes are localized within a $66.5 \mathrm{~kb}$ cluster on human chromosome $17 \mathrm{q} 23$ (15). The proteins encoded by the genes in this cluster have a complex mechanism of action and regulation in both the pregnant mother and the fetus $(15,16)$. Of note, fetal growth is mainly affected by human somatomammotropins via their effects on the GH receptor or the prolactin receptor. In addition to direct effects on fetal growth, these hormones have indirect effects that are mediated by insulin-like growth factors $(15,16)$. Along with other growth factors, human somatomammotropin regulates insulin-like growth factors production and modulates intermediary metabolism, including the availability of glucose and amino acids to the fetus $(15,16)$. Sheep and cattle adapt to poor fetal growth by increasing somatomammotropin activity in the fetal circulation $(14,17)$. Our finding that the three $C S H$ genes are the most highly upregulated among smokers may reflect a similar adaptive response. In addition to its association with lower birth weight, maternal smoking increases the risk of childhood obesity (18). In view of this, and the findings reported here, it is interesting that the growth hormone-lactogen gene cluster has been implicated in the association between low birth weight and the risk of metabolic syndrome later in life (19).

A number of growth factor signaling/direct growth promotion genes also showed differential expression in UC tissue obtained from smokers. Similarly, downregulation of the CEACAM6 gene could lead to a delay in the termination of insulin's action, with growth promoting effects (20). The increased expression of the ITSN1 (intersectin) gene may serve to increase epidermal growth factor-receptor turnover, another growth-enhancing adaptation (21). Increased expression of CRIM1, whose protein product promotes capillary tube formation (22) and decreased expression of SERPINB13 [which encodes an inhibitor of angiogenesis (23)] may promote angiogenesis and fetal growth. Finally, upregulation of another gene, the tenascin gene [TSN; which promotes tissue healing and regeneration (24)], could contribute to the development of extracellular matrix (i.e. fibroblasts and smooth muscle cells) in the offspring of smokers.

Another potential interaction of genes that were differentially expressed involves the downregulation of SERPINB2 (which encodes a plasminogen activator inhibitor-2, which may decrease tissue remodeling by inhibiting the plasminogen activators (25). The effects of decreased expression of SERPINB2 may be augmented by increased expression of ACTN4, which encodes actinin alpha 4, a protein that interacts with SERPINB2 and modulates its effects (26).

Two genes involved in the myosin chain showed increased expression in smokers. One of them, MYH10, is important in hypoxia-related myocardial adaptation (27) and the other, MYH11, is associated with arterial smooth muscle stiffening (28). It is noteworthy that stiffening of arteries is seen in infants with intra-uterine growth retardation (29). Further, one of the downregulated genes, SCEL (which encodes sciellin), is involved in stress-bearing blood vessel remodeling (30).

Some of the genes downregulated in cord tissue of smokers may provide immune and barrier protection (31). The most 
highly downregulated gene, $A P O B E C 3 A$, is a protooncogene with presumed protective immune function through its action as a cytidine deaminase (32). Decreased expression of $M A L$ (33), MAL2 (34), and KRT6B may result in impaired epithelial barrier protection. Other downregulated genes, A2ML1 (35), LCN2 (36), and EHF (37), are associated with impaired immune cell function. Reduced expression of SerpinB7, and a lower concentration of its protein product megsin (which plays a role in megakaryocyte differentiation) may contribute to the development of thrombocytopenia that is seen in intrauterine growth retardation infants (38).

These findings provide insight into potential processes by which the fetus adapts to the adverse effects of maternal smoking. Strengths of this study include the well-defined study population, use of clinical variables to adjust for potential confounds in the analysis of the microarray results, and the validation of key findings using qPCR technology. One limitation of the study is that smoking could not be validated biochemically due to the inadequacy of infant hair samples for cotinine analysis. However, subjects were informed that their smoking status would be validated, which by itself can reduce reporting bias, particularly in relation to smoking. Further, the most common reporting bias in pregnant smokers is nondisclosure of smoking (39), which would have reduced the differences in gene expression seen between groups. Finally, although we adjusted for clinical variables that differed as a function of smoking status, it is possible that other variables that were not adjusted for will have influenced the results, including the clustering of groups based on smoking status.

In summary, we found that 545 genes were differentially expressed in the fetal tissue of offspring born to women who smoke. These findings require replication and subsequent studies should examine the potential mechanisms (e.g. epigenetic modification) by which maternal smoking exerts adverse effects on the fetus. Larger-scale studies are also needed to correlate gene expression results with longer-term clinical outcomes.

Acknowledgments. We thank Christine Abreu, Pamela Fall, John Glynn, Anupinder Kaur, Shama Praveen, Bruce Morris and Denise Ortiz in this work for their technical assistance. We also thank the other members of our tobacco research group (Marc Lalande, Henry Furneaux, Melinda Saunders, Anna Dongari-Batzoglou, John Greene, and Roxanne Stepnowski) who participated in valuable discussions during the conduct of the study and the analysis of study findings.

\section{REFERENCES}

1. Walsh RA 1994 Effects of maternal smoking on adverse pregnancy outcomes: examination of the criteria of causation. Hum Biol 66:1059-1092

2. Kristensen S, Salihu HM, Keith LG, Kirby RS, Fowler KB, Pass MA 2007 SGA subtypes and mortality risk among singleton births. Early Hum Dev 83:99-105

3. Barker DJ, Eriksson JG, Forsen T, Osmond C 2002 Fetal origins of adult disease: strength of effects and biological basis. Int J Epidemiol 31:1235-1239

4. Stratton KR, Shetty P, Wallace R, Bondurant S 2001 Clearing the Smoke: Assessing the Science Base for Tobacco Harm Reduction. Washington, DC: National Academy Press, pp 148-158

5. Ulm MR, Plockinger B, Pirich C, Gryglewski RJ, Sinzinger HF 1995 Umbilical arteries of babies born to cigarette smokers generate less prostacyclin and contain less arginine and citrulline compared with those of babies born to control subjects. Am J Obstet Gynecol 172:1485-1487
6. Chirgwin JM, Przybyla AE, MacDonald RJ, Rutter WJ 1979 Isolation of biologically active ribonucleic acid from sources enriched in ribonuclease. Biochemistry 18:5294-5299

7. Li J, Wong L 2001 Emerging patterns and gene expression data. Genome Inform $12: 3-13$

8. Kerr MK, Martin M, Churchill GA 2000 Analysis of variance for gene expression microarray data. J Comput Biol 7:819-837

9. Dennis G Jr, Sherman BT, Hosack DA, Yang J, Gao W, Lane HC, Lempicki RA 2003 DAVID: database for annotation, visualization, and integrated discovery. Genome Biol 4:3

10. DiFranza JR, Lew RA 1995 Effect of maternal cigarette smoking on pregnancy complications and sudden infant death syndrome. J Fam Pract 40:385-394

11. Wang X, Zuckerman B, Pearson C, Kaufman G, Chen C, Wang G, Niu T, Wise PH, Bauchner H, Xu X 2002 Maternal cigarette smoking, metabolic gene polymorphism, and infant birth weight. JAMA 287:195-202

12. Huuskonen P, Storvik M, Reinisalo M, Honkakoski P, Rysa J, Hakkola J, Pasanen M 2008 Microarray analysis of the global alterations in the gene expression in the placentas from cigarette-smoking mothers. Clin Pharmacol Ther 83:542-550

13. Angiolini E, Fowden A, Coan P, Sandovici I, Smith P, Dean W, Burton G, Tycko B, Reik W, Sibley C, Constancia M 2006 Regulation of placental efficiency for nutrient transport by imprinted genes. Placenta 27:S98-S102

14. Oliver MH, Hawkins P, Harding JE 2005 Periconceptional undernutrition alters growth trajectory and metabolic and endocrine responses to fasting in late-gestation fetal sheep. Pediatr Res 57:591-598

15. Osafo J, Wei Y, Kenth G, Goodyer CG 2005 Growth hormone during development. Rev Endocr Metab Disord 6:173-182

16. Handwerger S, Freemark M 2000 The roles of placental growth hormone and placental lactogen in the regulation of human fetal growth and development. J Pediatr Endocrinol Metab 13:343-356

17. Holland MD, Hossner KL, Williams SE, Wallace CR, Niswender GD, Odde KG 1997 Serum concentrations of insulin-like growth factors and placental lactogen during gestation in cattle. I. Fetal profiles. Domest Anim Endocrinol 14:231-239

18. Wideroe M, Vik T, Jacobsen G, Bakketeig LS 2003 Does maternal smoking during pregnancy cause childhood overweight? Paediatr Perinat Epidemiol 17:171-179

19. Day IN, Chen XH, Gaunt TR, King TH, Voropanov A, Ye S, Rodriguez S, Syddall HE, Sayer AA, Dennison EM, Tabassum F, Barker DJ, Cooper C, Phillips DI 2004 Late life metabolic syndrome, early growth, and common polymorphism in the growth hormone and placental lactogen gene cluster. J Clin Endocrinol Metab $89: 5569-5576$

20. Najjar SM 2002 Regulation of insulin action by CEACAM1. Trends Endocrinol Metab 13:240-245

21. Martin NP, Mohney RP, Dunn S, Das M, Scappini E, O’Bryan JP 2006 Intersectin regulates epidermal growth factor receptor endocytosis, ubiquitylation, and signaling. Mol Pharmacol 70:1643-1653

22. Glienke J, Sturz A, Menrad A, Thierauch KH 2002 CRIM1 is involved in endothelial cell capillary formation in vitro and is expressed in blood vessels in vivo. Mech Dev 119:165-175

23. Shellenberger TD, Mazumdar A, Henderson Y, Briggs K, Wang M, Chattopadhyay C, Jayakumar A, Frederick M, Clayman GL 2005 Headpin: a serpin with endogenous and exogenous suppression of angiogenesis. Cancer Res 65:11501-11509

24. Chiquet-Ehrismann R, Chiquet M 2003 Tenascins: regulation and putative functions during pathological stress. J Pathol 200:488-499

25. Hu ZY, Liu YX, Liu K, Byrne S, Ny T, Feng Q, Ockleford CD 1999 Expression of tissue type and urokinase type plasminogen activators as well as plasminogen activator inhibitor type-1 and type- 2 in human and rhesus monkey placenta. J Anat 194:183-195

26. Magdolen U, Schroeck F, Creutzburg S, Schmitt M, Magdolen V 2004 Non-muscle alpha-actinin-4 interacts with plasminogen activator inhibitor type-1 (PAI-1). Biol Chem 385:801-808

27. Hashimoto T, Yamasaki S, Taguchi S 2003 Alterations in the expression of myosin heavy chain isoforms in hypoxia-induced hypertrophied ventricles in rats. Comp Biochem Physiol B Biochem Mol Biol 136:139-145

28. Zhu L, Vranckx R, Khau Van Kien P, Lalande A, Boisset N, Mathieu F, Wegman M, Glancy L, Gasc JM, Brunotte F, Bruneval P, Wolf JE, Michel JB, Jeunemaitre X 2006 Mutations in myosin heavy chain 11 cause a syndrome associating thoracic aortic aneurysm/aortic dissection and patent ductus arteriosus. Nat Genet 38: 343-349

29. Mori A, Uchida N, Inomo A, Izumi S 2006 Stiffness of systemic arteries in appropriate- and small-for-gestational-age newborn infants. Pediatrics 118:10351041

30. Young PP, Modur V, Teleron AA, Ladenson JH 2005 Enrichment of genes in the aortic intima that are associated with stratified epithelium: implications of underlying biomechanical and barrier properties of the arterial intima. Circulation 111:23822390

31. Simchen MJ, Beiner ME, Strauss-Liviathan N, Dulitzky M, Kuint J, Mashiach S, Schiff E 2000 Neonatal outcome in growth-restricted versus appropriately grown preterm infants. Am J Perinatol 17:187-192

32. Navaratnam N, Sarwar R 2006 An overview of cytidine deaminases. Int J Hematol 83:195-200

33. Marazuela M, Acevedo A, Adrados M, Garcia-Lopez MA, Alonso MA 2003 Expression of MAL, an integral protein component of the machinery for raftmediated pical transport, in human epithelia. J Histochem Cytochem 51:665-674

34. Marazuela M, Acevedo A, Garcia-Lopez MA, Adrados M, de Marco MC, Alonso MA 2004 Expression of MAL2, an integral protein component of the machinery for basolateral-to-apical transcytosis, in human epithelia. J Histochem Cytochem 52:243-252 
35. Galliano MF, Toulza E, Gallinaro H, Jonca N, Ishida-Yamamoto A, Serre G, Guerrin M 2006 A novel protease inhibitor of the alpha2-macroglobulin family expressed in the human epidermis. J Biol Chem 281:5780-5789

36. Bjorkqvist M, Kallman J, Fjaertoft G, Xu S, Venge P, Schollin J 2004 Human neutrophil lipocalin: normal levels and use as a marker for invasive infection in the newborn. Acta Paediatr 93:534-539

37. van Dijk TB, Baltus B, Caldenhoven E, Handa H, Raaijmakers JA, Lammers JW, Koenderman L, de Groot RP 1998 Cloning and characterization of the human interleukin-3 (IL-3)/IL-5/granulocyte-macrophage colony-stimulating factor receptor betac gene: regulation by Ets family members. Blood 92:3636-3646

38. Silverman GA, Bird PI, Carrell RW, Church FC, Coughlin PB, Gettins PG, Irving JA, Lomas DA, Luke CJ, Moyer RW, Pemberton PA, Remold-O'Donnell E, Salvesen GS, Travis J, Whisstock JC 2001 The serpins are an expanding superfamily of structurally similar but functionally diverse proteins. Evolution, mechanism of inhibition, novel functions, and a revised nomenclature. J Biol Chem 276:3329333296

39. Pichini S, Basagana XB, Pacifici R, Garcia O, Puig C, Vall O, Harris J, Zuccaro P, Segura J, Sunyer J 2000 Cord serum cotinine as a biomarker of fetal exposure to cigarette smoke at the end of pregnancy. Environ Health Perspect 108:1079-1083

40. Hofmann O, Mould R, Brittain T 1995 Allosteric modulation of oxygen binding to the three human embryonic haemoglobins. Biochem J 306:367-370

41. Rahman L, Bliskovski V, Kaye FJ, Zajac-Kaye M 2004 Evolutionary conservation of a 2-kb intronic sequence flanking a tissue-specific alternative exon in the PTBP2 gene. Genomics 83:76-84
42. Wang LC, Swat W, Fujiwara Y, Davidson L, Visvader J, Kuo F, Alt FW, Gilliland DG, Golub TR, Orkin SH 1998 The TEL/ETV6 gene is required specifically for hematopoiesis in the bone marrow. Genes Dev 12:2392-2402

43. De Leon H, Scott NA, Martin F, Simonet L, Bernstein KE, Wilcox JN 1997 Expression of nonmuscle myosin heavy chain-B isoform in the vessel wall of porcine coronary arteries after balloon angioplasty. Circ Res 80:514-519

44. Michl P, Knobel B, Downward J 2006 CUTL1 is phosphorylated by protein kinase A, modulating its effects on cell proliferation and motility. J Biol Chem 281:1513815144

45. Sun Y, Ding L, Zhang H, Han J, Yang X, Yan J, Zhu Y, Li J, Song H, Ye Q 2006 Potentiation of Smad-mediated transcriptional activation by the RNA-binding protein RBPMS. Nucleic Acids Res 34:6314-6326

46. Dong Z, Zhang JT 2006 Initiation factor eIF3 and regulation of mRNA translation, cell growth, and cancer. Crit Rev Oncol Hematol 59:169-180

47. Bustelo XR, Sauzeau V, Berenjeno IM 2007 GTP-binding proteins of the Rho/Rac family: regulation, effectors and functions in vivo. Bioessays 29:356-370

48. Scholzel S, Zimmermann W, Schwarzkopf G, Grunert F, Rogaczewski B, Thompson J 2000 Carcinoembryonic antigen family members CEACAM6 and CEACAM7 are differentially expressed in normal tissues and oppositely deregulated in hyperplastic colorectal polyps and early adenomas. Am J Pathol 156:595-605

49. Schweizer J, Bowden PE, Coulombe PA, Langbein L, Lane EB, Magin TM, Maltais L, Omary MB, Parry DA, Rogers MA, Wright MW 2006 New consensus nomenclature for mammalian keratins. J Cell Biol 174:169-174 